\title{
QUALITATIVE STUDY ON PET-RELATED HUMAN BEHAVIOUR AND OTHER RISK FACTORS OF RABIES IN BULELENG, BALI
}

\author{
Komang Hendra Setiawan ${ }^{1)}$, Ketut Indra Purnomo²), \\ IP Adi Wibowo3), Made Kurnia Widiastuti Giri4) \\ Ganesha University of Education, Bali
}

\begin{abstract}
ABSTRAK
BACKGROUND: Bali has been an endemic province since 2008. Rabies cause specific death was 8, 1, and 2, respectively, in 2012, 2013, and 2014. Number of dog or cat bites was 55836, 44690, and 46877, respectively, in 2012, 2013, and 2014. The study aimed to explore pet-related human behavior and other risk factors of rabies in Buleleng, Bali.

SUBJECT AND METHODS: This was a qualitative study conducted in poor communities living in Bulian village, Kubutambahan sub-district, Buleleng district, Bali. Twenty households were purposively selected for this study. The key informants included household members, heads of hamlet, and head of village. The data were collected by in-depth interview, direct observation, and document review.

RESULTS: House condition and sanitation were acceptable, despite low socio-economic position of community members. Dog population was high. Most of them lived wild, unattended, or did not have identity necklace. Ten out of 20 household interviewed reported that their members were bitten by dog over the past year. Most of the dogs had never been vaccinated. Most of the villagers had poor knowledge and practice on how to treat wounds. Villagers usually let the dogs that had bitten human to live free or killed them immediately.

CONCLUSION: Uncontrolled of dog population, widespread unvaccinated dogs, uncontrolled dog mobility, lack of proper knowledge and practice on wound treatment, were the main risk factors of rabies incidence.
\end{abstract}

Keywords: rabies, dog bite, pet-related human behavior, risk factor 